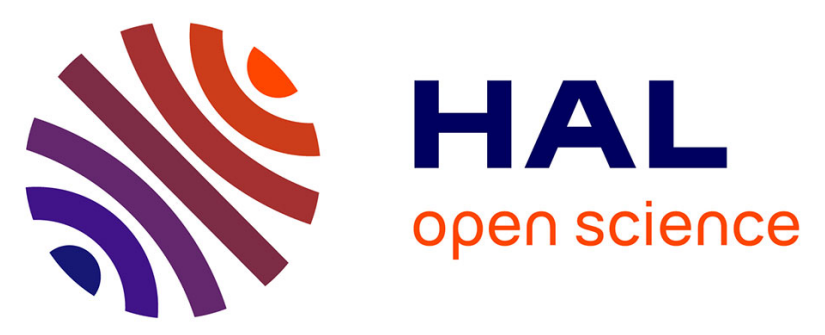

\title{
The Strength of Weak Heritages: Urbanity, Utopias and the Commitment to Intangible Heritage
}

\author{
Michel Rautenberg
}

\section{To cite this version:}

Michel Rautenberg. The Strength of Weak Heritages: Urbanity, Utopias and the Commitment to Intangible Heritage. Pardo, Italo, Prato Giuliana (eds.), The Palgrave Handbook of Urban Ethnography, New York, Palgrave-Macmillan, https://doi.org/10.1007/978-3-319-64289-5_17, pp.297 - 313, 2017, 10.1007/978-3-319-64289-5 . halshs-01664578

\section{HAL Id: halshs-01664578 \\ https://shs.hal.science/halshs-01664578}

Submitted on 8 Sep 2018

HAL is a multi-disciplinary open access archive for the deposit and dissemination of scientific research documents, whether they are published or not. The documents may come from teaching and research institutions in France or abroad, or from public or private research centers.
L'archive ouverte pluridisciplinaire HAL, est destinée au dépôt et à la diffusion de documents scientifiques de niveau recherche, publiés ou non, émanant des établissements d'enseignement et de recherche français ou étrangers, des laboratoires publics ou privés. 


\section{Metadata of the chapter that will be visualized online}

\begin{tabular}{|c|c|}
\hline Chapter Title & $\begin{array}{l}\text { The Strength of Weak Heritages: Urbanity, Utopias and the Commitment } \\
\text { to Intangible Heritage }\end{array}$ \\
\hline Copyright Year & 2018 \\
\hline Copyright Holder & The Author(s) \\
\hline \multirow[t]{8}{*}{ Corresponding Author } & Family Name \\
\hline & Particle \\
\hline & Given Name \\
\hline & Suffix \\
\hline & Division \\
\hline & Organization/University \\
\hline & Saint-Etienne, France \\
\hline & michel.rautenberg@univ-st-etienne.fr \\
\hline Abstract & $\begin{array}{l}\text { Rautenberg casts his discussion in the current context of strong heritage policies } \\
\text { and local passions and interests, which he calls 'weak heritages' because of } \\
\text { their very low level of institutionalisation. He examines two ethnographies: } \\
\text { Villeurbanne, a town near Lyon that has traditionally hosted refugee and } \\
\text { migrant associations, and Villeneuve d'Ascq, in the north of France, where } \\
\text { pioneers' utopia of country town was established in the 1970s. In both cases, } \\
\text { in opposition to official policies, 'weak' local heritage has succeeded in } \\
\text { preserving local practices and parts of landscapes to which people are attached. } \\
\text { Both cases involve what Rautenberg calls 'social heritage', whose strength, he } \\
\text { argues, lies in their plasticity. They do not belong to anybody, can appeal to a } \\
\text { range of new social arenas and make people feel that they are the inheritors of } \\
\text { a history. }\end{array}$ \\
\hline
\end{tabular}

\section{AUTHOR QUERIES}

Q1 Please check and confirm the affiliation details and amend if necessary. 


\title{
Author's Proof
}

\section{The Strength of Weak Heritages: Urbanity, 2 Utopias and the Commitment to Intangible 3 Heritage}

\author{
Michel Rautenberg
}

\section{INTRODUCTION}

Anthropologists and, more broadly, all of the social sciences have renewed their interest in reflecting on the concepts of heritage and of community, ever since international organizations such as the United Nations Educational, Scientific and Cultural Organization (UNESCO) and the Council of Europe began promoting them, linking the two concepts to each other (Labadi 2013), for the purpose of hastening the processes of democratization among the various countries of the world and also within each country (Adell et al. 2015), as well as encouraging the sustainability of individual regions (Auclair and Fairclough 2015 ). One of the nodal points of these new policies is the emphasis placed on proximity in heritage practices, which results, within cities, in a renewed interest in neighbourhoods (Morell and Franquesa 2011) and in the furthering of the idea of a 'community of practices' (Adell et al. 2015). A community of practices is built on the model of communities of learners, developed by Etienne Wenger (1998), who argues that individuals from a variety of backgrounds and with different interests can work together effectively as long as they share a goal and manage their negotiations jointly. The idea that, more or less explicitly, underlies these policies is that heritage carries with it a liberating power. This idea that was developed, among others, by the Council of Europe Framework Convention on the Value of Cultural Heritage for Society, signed

Translated by Marie Deer.

M. Rautenberg $(\bowtie)$

University Jean Monnet, Saint-Etienne, France

(C) The Author(s) 2018

I. Pardo, G.B. Prato (eds.), The Palgrave Handbook of Urban

Ethnography, https://doi.org/10.1007/978-3-319-64289-5_17 


\section{Author's Proof}

M. RAUTENBERG

in 2005. ${ }^{1}$ In other words, there is a potential direction that heritage could take that passes through empowerment. However, it is important to remember that the concept of empowerment is as ambiguous as it is rich. It is backed by starkly differing policies and ideologies, from the neoliberal views that were developed in Margaret Thatcher's Great Britain, for example (Dicks 2000), to the radical standpoints of postcolonial studies (Bacqué and Biewener 2013). Thus the heritagization of neighbourly customs and networks, which constitute both a practice and a fundamental value of urbanity, connects old and new residents, the development of tourism, and the protection and maintenance of the quality of life, international political processes and the management of localism, depending on the various political stakes, which may be in conflict with each other (Morell 2015). The heritagization of this urbanity, which has become a major issue in urban practices and politics (Rautenberg 2015a), creates new urban territories and reorganizes living environments, as Morell (2015) has clearly shown for Palma de Mallorca.

While emphasizing that location in public action is a governance style that makes very good use of heritage, it would be a mistake to reduce all heritage action to localism. Palma de Mallorca is a very good example of urban public policies and individual issues of gentrification coming together to contribute to the heritagization of several of the city's formerly industrial and working-class districts. Heritage can also be a driver for the mobilization of residents, citizens and anyone else who might be working for a particular cause. Thus we will see that in Villeneuve d'Ascq, a new French city, the memory of utopias that is built into the city's origins and still contributes to its current urbanity can be mobilized under certain circumstances-for instance, as a way to fight against changes that the residents consider harmful. This is a kind of heritage that we will call 'weak' because it has not gone through any of the instances or procedures of heritage institutionalization, such as the Council of Europe's not very formalized recognition. Looking at another situation, the 50th anniversary celebration of a cultural association that is engaged in intercultural activities in the region of Lyon, I highlight another kind of 'weak' heritage, which in this case is made up of the values that the group has stood for from its beginnings. I then propose that these forms of heritage end up becoming intermingled with the process that brings them to light-in other words, it is in the actions of the residents rather than in preservation by the institutions where heritagization resides.

\section{Residential Engagement in 'Weak' or Non-institutional Forms of Urban Heritage}

The heritage field has grown considerably in recent decades, especially since UNESCO ratified the 2003 Convention for the Safeguarding of Intangible Cultural Heritage (Smith and Akagawa 2009). This has resulted in heightened tension between the two main forms of heritage: heritage that is called 'fixed' in the past and in a territory, in particular that of monuments or archaeological 


\section{Author's Proof}

remains; and a 'more mutable heritage centred very much on the present' (Smith and Akagawa 2009, 2). Heritage is no longer a noteworthy exception in our environment; it belongs to our daily landscape. It has become one of the chief tools for sustainable development policies, especially in our cities, where it is connected with social cohesion and citizen involvement (Auclair and Fairclough 2015). It is also involved in the mobilization of residents against political projects or development projects_-private or state run-that threaten to change valued lifestyles or places (Hocquet 2013). This heritage boom has therefore forced local and national officialdom to reassess its basic assumptions and take note of popular movements and grassroots heritage practices, like those arising from neighbourhood networks and not always aligned with public policies or the interests of economic actors. People cherish this collection of practices and lasting bonds with their environment and are willing to mobilize for its distribution and protection. This is what I am calling 'weak heritage'. These are not objects, buildings or places that connect us to 'our' city but ideas, images, values and social relations that are part of our urbanity and that we would like to sustain (Rautenberg 2015a), although they may eventually be embodied in physical locations. I hope that the reader will forgive my bit of humour in calling this heritage 'weak', not to evoke its fragility but to emphasize how weakly institutionalized it is, as suggested in Granovetter's wellknown text (1983). Spread by people who do not know each other very well or even at all, move in different social orbits and live in different neighbourhoods or towns, these 'weak' heritages mainly mobilize people who are in a position to widen the circle of those who might feel implicated, which gives an unexpected extra reach to this kind of heritage. On the one hand, this kind of citizen mobilization often goes through 'heritage communities of practice'proposed by new heritage policies and promoted by the Council of Europe, these are intended to both manage and protect the transmission of the heritage under their responsibility. The states that make up UNESCO, on the other hand, continue to promote heritage that upholds their national unity (Adell et al. 2015). UNESCO, supported by non-governmental organizations and citizens' groups, especially those involved in protecting indigenous people, also places great importance on participation, recycling the strategies of the emancipation pedagogy of the 1970s and connecting them to the rediscovery of localism, to which heritage is presumed to give new value, as it does to the defence of cultural rights. This approach, in an almost counter-hegemonic way, attempts to protect communities, while the international organization, along with the vast majority of the states that constitute it, promotes a neoliberal ideological model of conservation, encouraging the commodification of heritage. Although they were not particularly concerned by that model at first, communities of practice have become increasingly important within urban heritage as the intangible cultural heritage concept has fostered a wide-scale embrace of urban spaces by urban residents, far beyond what is recognized by UNESCO. However, these alternative, non-institutional heritagization processes have to find a place within urban renewal policies that have other goals. 


\section{Author's Proof}

M. RAUTENBERG

During the 'entrepreneurial turn' of the 1980s (Harvey 1989), European cities developed new governmental models favouring the 'project' over older bureaucratic models (Le Galès 2003), while capitalism was being transformed and the citizenry was demanding greater involvement in managing its daily environment. Citizens, concerned with protecting their quality of life, became more heavily invested in culture and heritage, traditionally the domain of public policies. Neighbourhoods became the subject of renewed governmental concern. They went from being territories defined above all by residential involvement and the spatial organization of the city to being political issues, mired in new forms of governance that were trying to reconcile governmental decisions with popular opinion. The neighbourhood found itself 'encapsulated' in the vertical structure of public policies, to the advantage of certain entrepreneurs, 'snakes' who know how to climb the 'ladders' of power through their favourable positions within the networks (Morell and Franquesa 2011). The neighbourhood played an important role in idealizing proximity, leading to a proliferation of governmental projects to conserve and protect the cultural landscape (Bandarin and Van Oers 2014), localism (Morell 2015) and the multicultural environment (Salzbrunn 2015). Increasingly, urban regeneration policies work with the population, as a collection of 'communities' of residents that take responsibility for the transformation of their neighbourhoods for the European Union and as 'heritage communities' carrying out the actions necessary for the preservation of their unique identities for UNESCO (Morell and Franquesa 2011, 199-201). The real issues behind heritage and neighbourhood are the decentralization of public decision-making, taking it closer to the residents, and the revival of the real-estate market. Morell (2015) shows the contradiction between these two issues.

This analysis shows that we must find a way to connect the preservation of the living environment, the evolutions in local governance and capitalism's double turning point - entrepreneurial and cultural— to all of which cities must adapt. Are all cities equally affected by this imperative towards communication and urban marketing? Does this phenomenon erase all other forms of urban lifestyle preservation? For tourism-driven Palma de Mallorca, Morell and Franquesa show that residents were able to assert other heritage forms and practices. Isnart (2015) shows how on the Island of Rhodes, also strongly marked by its medieval past, alternative heritage forms were able to surface in the process of defending a Catholic religious heritage for its own sake, unconnected to the Crusade-tourism sightseeing circuits. The fashion for urban marketing hides the more complex heritagization practices that residents engage in for causes other than promoting their city or economy.

The two ethnographic cases on which I will now focus illustrate the 'weak' form of heritage mentioned earlier. In both cases, it is the commitment to a cause, expressed through specific, regular actions, that breathes life back into the heritage. This kind of heritage is flexible, with contours defined through action and storytelling rather than governmental protection and policies, and it evokes a kind of 'heritage conscience ... circumscribed in experience', a 


\section{Author's Proof}

THE STRENGTH OF WEAK HERITAGES: URBANITY, UTOPIAS...

'feeling of the past' (Tornatore 2006, 526), rather than the groups of buildings or objects of which inventories are made. This kind of heritage belongs to no one, except for the heritage communities of practice, whose boundaries change from one event to the next.

\section{Villeneuve D’AscQ: ‘Weak' Heritage Forms of an Urban} UTOPIA

Villeneuve d'Ascq is located in the suburbs of Lille in northern France. The expansion of this city is rooted in the urban utopias of the 1960s that followed the modernist movement (Rautenberg 2015b). In some neighbourhoods, the city illustrates the utopia of a 'country town' and of a more democratic operation, allowing for a variety of mechanisms for local democracy. ${ }^{2}$ The research we did there from 2003 to 2006 shows that the first residents, who considered themselves 'pioneers', aimed to protect their immediate environments and the cooperative practices to which they were particularly attached, and which some of the newer residents were able to revive. Between the late 1960s and the early 1980s, the developers, architects and urban planners who designed and built the city wanted to give it an identity in line with the modernity of the time: green spaces, sporting facilities, cultural sites, support for new-technology companies and participatory democracy; a mix of individual and collective housing, of home ownership and subsidized housing. This period fell between the end of urban design's heyday, under the stewardship of governmental bridge and highway engineers and public works departments, and the beginnings of 'functional urban planning', which drew inspiration from the May 1968 movement and for which the new cities were the favourite field of operation. However, the proposals of the state's urban development department in charge of the project show some difficulty in seriously considering the territory's existing social and political realities as anything other than constraints (elected officials and residents were accused of hindering the functioning of the project) or as resources (strengthening the sense of a 'natural setting' that was desirable for the new city, just like the old farmsteads). One gets the impression that the planners would have preferred to have built on a vacuum. The 12,000 people who lived in the area before the city was created are only mentioned in passing in contemporary speeches and local newspaper reports. They continue to stay in the shadows in the following decades. At the same time, there are many speeches about the participation of the 'residents', betraying a real concern, on the part of both the urban development technicians and planners and the new city's elected officials, about building a city that was supposed to be more 'democratic'.

In many ways, Villeneuve d'Ascq looks like the realization of a utopia. It approximates the tripartite structure of Thomas More's Utopia (Choay 1965). First, it critiques what it supplants (here, functionalism and the housing projects that supposedly dehumanized the city). Second, its project is to create a more harmonious society (i.e. the city). Third, it conceives the built-up space as a bridge between city and nature, founded on more democratic institutions 


\section{Author's Proof}

M. RAUTENBERG

with the goal of 'changing the city'-in other words, a space that moves away from the old urban age to a new urban age. This desire is not new; it has been part of the development of most new French cities. Even now, more than 40 years later, these utopian ideas are not forgotten by long-time residents, the city's architects and certain elected officials. They have become part of a kind of intangible cultural heritage which is still sometimes embodied in city planning to this day. Let us expand a little on these three main utopian ideas.

The first utopia is rather intangible. It involved creating an urban life that was different from the rejected urban past of large apartment buildings and the 'spectre of bedroom communities' (Vadelorge 2003). We call this utopia 'the opening'. It can be seen as a local paradigm shared by both those who conceived it and many residents. It is visible in architectural choices and social practices, as many pioneers from the 'golden age' of the first years remember. This idea is what gives coherence to the project of the new city, unifying the built-up space and the social, the practices and the dreams. It explains the prohibition on closing off gardens with tall hedges so that interactions can take place, the choice of certain homeowners not to fence off their property, and the presence of public paths that snake between the houses. But it can also be seen in the welcome given to Chilean and Vietnamese refugees during the 1970s and the decisions to devote $50 \%$ of the housing stock to affordable or subsidized housing and to give priority to innovative companies. In other words, Villeneuve d'Ascq was supposed to be an open city, promoting social progress, in which the quality of the social relations was supposed to be the key to 'changing the world'.

The second idea has to do with the promotion of local democracy, built on a system of meetings, which was promoted by the government's planning department in order to exchange information between the population and the professionals. Here the technicians present their projects to the population, including the long-time residents of the three municipalities and the first residents of the new neighbourhoods. The atmosphere can become tense when the residents believe that their points of view are not being heard. Later, other systems were set up to allow organizations, elected officials and residents to work together on issues of interest to them all, including the management of public facilities, the establishment of day-to-day ecological routines, building permits, investment projects and the organization of neighbourhood parties. However, these systems eventually failed.

The third utopian idea is that of mixing city and countryside, following the old and well-known dream, or more specifically bringing nature into the city, consciously rebutting modernist functionalism. This explains the importance given to green spaces, private gardens and the greening of public spaces, now seen as recreational spaces, not simply sites of pleasure, as they often were in older French cities. The last farming operations are also preserved, treated as almost sacred and more as heritage sites than anything else. 


\section{Author's Proof}

THE STRENGTH OF WEAK HERITAGES: URBANITY, UTOPIAS...

From Urban Utopias to the 'Imaginary in Act' of Local RESIDENTS

In the statements we collected from our interviews, many architects, planners, 246 leftist elected officials, and old and new residents appeared to share the utopias 247 of the time and a vaguely communitarian ideal of life. A sort of common vision, 248 a spirit of sharing, emerged. This generation, which a decade earlier had expe- 249 rienced the events of May 1968 (some from very close up), with its demonstra- 250 tions and occupying of universities, had not lost its illusions of a better world. 251 The people who arrived in the new city were hoping for a friendlier, less con- 252 ventional way of life. They wanted to build an ideal city, to forge amicable 253 social connections, to carry out collective actions, to show solidarity. These 254 new residents of Villeneuve were heavily invested in community life. They were carrying the torch for what appeared, then, to be modernity, and it seemed as though the new city was going to make it possible for these projects to blossom. Some of the pioneers, who in the past had had positions of responsibility in trade unions, politics, or community clubs and groups, took the lead when it became necessary to defend special interests that turned into collective claims. They became engaged in developing neighbourhood activities or in joint proprietor associations. From the beginning, the new city allowed, and even encouraged, the development of individual plans and ambitions.

These social imaginaries occurred within the context of the city's profound and long-lasting transformation, which followed the serious transformation of European cities that began in the 1950s with the 'democratization of space' that governments were trying to promote (Secchi 2004). However, as the example of Villeneuve d'Ascq shows, residents were able to resist these institutional frameworks. The organizations that had been intended as a way to manage the subdivisions became more demanding than expected or desired. Sometimes they turned into powerful local opposition groups against public officials. It turns out that when projects that have been imagined and designed in architectural firms and urban planning offices are realized and carried out, there are sometimes surprises in store as participatory utopia extends into social life.

The various agents involved in new cities often took charge of the narrative of their origins and their history very early on (Vadelorge 2003). Thus Villeneuve d'Ascq's political and democratic identity relies on sagas that emphasize the state's heavy-handed approach to its beginnings. They can be categorized as founding narratives, falling somewhere between mythology and history. They were echoed by a number of our interviewees and we found them again in various publications to do with the city, in the local press, in biographies and in historical works. These founding narratives can be structured into three major interrelated themes.

The first is that of a technocratic adventure that causes the city to emerge from the ground almost by magic. The best-known story, which exists in several different versions, is that of 'one of General de Gaulle's ministers' - that is, Edgar Pisani, the minister of public Works from 1966 to 1967—who, like a 


\section{Author's Proof}

M. RAUTENBERG

demiurge, is supposed to have flown over the site in a plane or a helicopter in order to decide on the placement of the city.

The second recurring theme involves the pioneers who went into battle against everyone-government authorities, developers and the urban community - to ensure that the city would live up to their residential dreams. Thus we find stories about protests 'against the defects' that people discovered in the apartments when they were first moving in; about the public authority's management of transportation routes in the subdivisions; about the opposition to the construction of the Alvaredo neighbourhood ${ }^{3}$; and about Gérard Caudron's first election, in 1977, when he ran on the platform of recalibrating the city's development plans, which he said had 'fallen into the hands of the technocrats'. ${ }^{4}$

The third theme is one that comes up most often; it is that of the lost solidarity of the early years, when neighbours helped each other, bought lawn mowers together and used them in common, welcomed new arrivals with a shared drink, and organized big midsummer bonfires on the plain in front of the castle.

Nowadays, these narratives run together to make up an activist myth for the city, one of the pillars of Villeneuve's social imaginary, along with its heritagist, urbanist and landscapist elements. The importance of the urban landscape, which has managed to combine some of the typical traits of northern France's urban culture with architectural modernity, should not be underestimated. The residents of Villeneuve are attached to the position of nature in their environment, to the passages and alleyways between the houses and to the little gardens that they tend in front of their dwellings, even when they are part of the communal property. One of the pleasures often mentioned is walking in the city, running or taking walks around the lakes. When asked why they decided to move here, many residents mention nature, the sense of an urban village, the city's 'openness to nature and the countryside.' Many of those we talked to were unaware that the lakes and ponds that can be found all over the city were actually created at the same time as the new city. In the area around the castle, where the kind of collective struggles that we have quickly described here never really took place, the local government recently revived the midsummer bonfires in celebration of Saint John that were initiated about 30 years ago by local parents and other residents.

The original values that were in place when the city was created are still partially present in the mental image that people have of the city, although the residents' practices have changed quite a bit and the old values have now largely been overlaid with more 'classical' images of heritage. According to some of the witnesses, since 1974, public spaces have become closed off. Residents have 'forgotten' to trim their hedges, thus impeding the kind of communication that can happen over the backyard hedge and, even more, the visibility of their yards and gardens from the outside. The ownership association regulations have been modified to allow yards to be closed off. 'People are barricading themselves in', we heard during our interviews. A number of public pathways 


\section{Author's Proof}

THE STRENGTH OF WEAK HERITAGES: URBANITY, UTOPIAS...

have been privatized. At the same time, mutually supportive relationships within neighbourhoods are no longer what they were. Finally, a reading of local newspapers and community newsletters indicates that Villeneuve's heritage has been the object of veritable institutional invention, as there is an insistence on emphasizing the least little vestige that might anchor the new city in old, or even ancient, soil.

If we only had institutional memory to go by, we might think that Villeneuve d'Ascq was a city like any other, whose history was rooted in the soil of northern France, in spite of the memories of some people and the practices of others. Ten years ago, the heritage of new cities was no respecter of utopias. And yet, what could look like a denial of collective memory continued to play its own part: however embellished or transformed they might be, the stories of the founding of the city and of some of the small events that dotted the history of its neighbourhoods had not been forgotten by the city's residents. They reactivated those memories whenever it came to recalling that the utopias of the past had not been erased, even if they were now more likely to fall into a private register or to have to do with neighbourhood socialization. This kind of memory was also mobilized for the sake of demanding that the public spaces be managed in a way that was more respectful of nature and to revive the manifestations and practices of neighbourliness. At the time when we were carrying out our research, these utopias were also invoked to argue against the construction of a large stadium on public territory, or to save a tree that was interfering with the flow of traffic from being cut down. They also appeared in the mayor's campaign speeches, when he reminded the city's inhabitants of how he resisted the government and its technocrats when he was first elected in 1977.

In this way, urban utopia seems to fit well with the social heritage of the city. Such 'social' heritage retains a real force, as well as a greater political and social efficacy than many of the city's more iconic heritage sites, such as the Flers 'castle', which is registered on the supplementary historic monument list. The following example, however, is based on a different kind of experience. It has to do with the treatment of interculturalism in a cultural organization. This is less about urbanity as space than it is about urbanity as a capacity of the city's residents-who associate the management of cultural otherness with lifestyles, knowledge, and practical and interpersonal skills-that constitutes an important part of the city's heritage.

The Jean-Pierre Lachaize Ecumenical Cultural Centre (Centre Culturel 371 (Ecuménique, CCO) in the town of Villeurbanne, near Lyon, was established 372 in the 1960s as a meeting place for students of the nearby university. Since the 373 beginning, the CCO was involved, on the one hand, in the social work of the 374 


\section{Author's Proof}

M. RAUTENBERG

district and in creating a network of social support there and, on the other hand, in helping immigrants, addressing political issues to do with relations between Europe and the third world, and providing support to refugees. When the centre celebrated its 50th anniversary, something about the activities of its membership that had never actually been made explicit finally became quite clear: their ongoing commitment, from the very beginning, to a principled sense of hospitality and to what we might today call the defence of cultural rights (Autant-Dorier and Aubry 2014). ${ }^{5}$ When the 'Cultural Centre for Chaplaincies and for Catholic and Protestant Services' was created by Father Jean Latreille in $1963,{ }^{6}$ it was mainly intended as a way to provide chaplaincy services to the students of the nearby university. Very quickly, starting with the centre's 1967 handbook, the students who used it were asked to be truly engaged and not to arrive with a 'consumer mentality' (quoted in Chatelan 2012). However, in 1971, Latreille noted that 'the term "welcome centre" would have been just as apt. Because it is a real caravansary. You can find everything there, the best and the not so good, prayers and folk dances, catechism circles and card games, a real bistro during the week and a parish on Sundays' (quoted in Chatelan 2012,21). The cultural centre had made itself open to the neighbourhood, but to some degree that was done to the detriment of its evangelical work and of the pastoral care of the students. Nevertheless, as the 1970s went on, the centre expanded, received new sources of funding from the town of Villeurbanne and in 1976 changed its name to the Ecumenical Cultural Centre, providing cultural events for the neighbourhood as well as chaplaincy services. The CCO does not intend to be just a place that 'rents out venues' but rather to remain a 'place of freedom, welcome and a meeting place for all those who work towards promoting humanity' (Chatelan 2012, 26). The centre makes itself available for training workshops and hosts evening debates for the women's commission of the French Communist Party, for the French Scouts, for the meetings of the neighbourhood merchants' association and for demonstrations in support of Tunisian students on hunger strike.

After this period of putting down roots in the community, a period of more intense activism followed in the 1980s. In that decade, the CCO developed pretty much in every direction, reaching out towards refugees, the unemployed, the underhoused and the youth. An increasing number of organizations were welcomed into the $\mathrm{CCO}$ and the permanent staff were expanded. In 1984 there were 176 organizations that met at the CCO, of which about 20 had their headquarters there. According to Chatelan, the diversity of activities made any kind of categorization virtually impossible: 'co-ownership boards, works councils and 'Christmas parties', ${ }^{7}$ charitable organizations, student organizations, meetings on various worldwide conflicts (as those in Northern Ireland and in El Salvador) took place side by side with theatrical and musical rehearsals, the latter showing a growth of 800 percent in terms of hours of presence in the building from 1987 to $1989^{\prime}(2012,30)$. True activism took a back seat in order to support the activities of cultural organizations or those linked to the immigrant communities. The CCO now saw itself as 'a place for the recognition and expression of different cultures', 'a promoter of action's 


\section{Author's Proof}

and an 'organization of organizations' as its members often defined it.' After intense internal discussions about the identity of the organization, in 1989 it drew up a charter in which two main priorities were identified: first, the CCO should function as the head of a network of organizations; second, its primary mission should be the fight against poverty in all its forms. In the following decade, the connection between the CCO and government services was significantly strengthened because of the demand placed on the CCO to participate in the policies for neighbourhood social development, ${ }^{10}$ in particular by contributing to the training of managers for urban projects. There was a significant increase in the financial resources available to the centre, especially thanks to the involvement of the state and because there was a substantial expansion of the subsidy it received from the municipal government. In the 2000s, cultural activities and the economy of social solidarity were enhanced. For the leaders of the centre, however, it was the prefix 'inter' that was the best way to characterize the activities of the CCO (renamed in 2003 as the Jean-Pierre Lachaize CCO after its charismatic director) - that is, interconnection with other organizations and interculturalism, framing a project that was now oriented towards 'integrating a rootedness in the local with a citywide presence; supporting individuals and human rights by paying particular attention to the excluded, in order to give them a voice' (Chatelan 2012, 36).

In the conclusion of his article about the $\mathrm{CCO}$, Chatelan emphasizes the centre's remarkable faithfulness to its origins. I would also point out its warmth, hospitality and openness. Chatelan proposes two hypotheses to explain the organization's success: first, the strong value put on reflection and intentionality, along with the intellectual foundation of which the centre has never lost sight; and, second, the idea that the CCO is a 'community'. The word 'community' was taken on at the beginning (in the context of the 'Community of Marist Brothers') but seldom used from then on, even though the idea that the $\mathrm{CCO}$ was supposed to be something more than a simple cultural organization was very widely shared among the board of directors, the paid staff and many of the people who used it. All of these stakeholders recognized that there was a 'CCO spirit'. How was this able to mobilize a 'community' of people who felt connected to the organization? That is what I shall now examine, through the lens of a particularly significant event in the centre's recent history-namely, the organization of its 50 th anniversary.

\section{The 50Th ANNIVERSARY}

In 2009, while the steering committee for the CCO's 50th anniversary was in the middle of its preparations and discussions, the director, Fernanda Leite, was asked: 'How does the CCO deal with the issue of balancing an appreciation for the contributions of these cultures with advocacy for intangible heritages?' She responded:

We pay attention to the idea of promoting the public expression [of cultures] and the ways in which they interact with others, with the intention of constantly renew- 


\section{Author's Proof}

M. RAUTENBERG

\begin{abstract}
ing their ability to be a language that moves freely in the world, in other words to be an expression that is disseminated by actors who are able to act ${ }^{11}$ and to formulate their way of 'being in the world', rather than worrying more narrowly about 'preserving a heritage' ... And while the CCO welcomes these 'heritages' in order to allow them to exist, the Words on the Spot event creates a space for interaction among them. Thus, they find new geographies and new horizons in order to exist with others and not to be closed in on themselves and, as a result, they renew themselves. ${ }^{12}$
\end{abstract}

This interview excerpt does a good job of summing up the organization's philosophy. Elsewhere it says that it wants to be an 'incubator'-that is, a place that allows groups to mature and that promotes the public expression of cultures in a spirit of sharing and of adaptation to current conditions. In this spirit, heritage is not a collection to be maintained; it is action, involvement, sharing and transformation.

The 50th anniversary was the object of lengthy preparations by a steering committee made up of board members, the directors and researchers who had been 'enlisted' in the action research that had been set in motion a year earlier. The anniversary was seen as an effective device through which each person involved, whatever their status, would be led to commit to a more active role 'in order to resolve some issues of legitimacy that had been getting in the way' (Autant-Dorier and Aubry 2014, 49) of a reflection on the heritage dimension of the CCO's activities. The plan was to involve everyone in the research, starting from wherever their place was in the organization: 'Thus, the paid staff members of the $\mathrm{CCO}$ were in fact involved in the anniversary initiative, whereas up until that point they had been, rather, witnesses to the research' (AutantDorier and Aubry 2014, 49). The problem for the staff members and activists was that it was 'less about leaving a mark than about becoming involved in the relationship and making things happen, 'working together' (Autant-Dorier and Aubry 2014, 51), and that it seemed awkward, all of a sudden, to think in terms of being motivated by heritage. This awkwardness was intensified by the fact that the chief characteristic of the CCO, the interculturalism that was the reason for all of this activity, was in fact external to the institution. It was, in fact, more a characteristic of the partner organizations, the city and even the world in which they were acting. So how could it be said to be connected to the organization's own heritage, even if only its intangible heritage? The suggestion was made to the members, whether elected or paid, that this would be an 'indirect' heritage- that is, not a direct characteristic of the CCO but rather a characteristic, primarily, of the organizations that it hosted and for which the $\mathrm{CCO}$ provided the possibility of it being put into action. In fact, for the $\mathrm{CCO}$, interculturalism would be primarily a 'political dimension of the action' (Autant-Dorier and Aubry 2014, 51) and therefore, in a way, that dimension could be considered characteristic of the CCO. That is what the 50th anniversary would bring about.

The anniversary celebration was held between 12 and 19 January 2013. The team of researchers was closely involved with events and activities of various 


\section{Author's Proof}

kinds that included writing a book sprint with an author from Quebec ${ }^{13}$; a study workshop with master's students entitled 'Citizen Sharing: (Inter)cultural Experimentations as a Mode of Citizen Activation' at which various experiments that had been conducted with artists and researchers were presented; a debate panel on the theme of 'cultural rights, universalism and communities'; a series of jointly conducted workshops on 19 January on the results of the book sprint, a 'speed dating' event on interculturalism, ${ }^{14}$ a workshop on the topic of 'building the $\mathrm{CCO}$ of tomorrow', a 'connections lab' intended to map the CCO's network and a CCO photo booth; the presentation of three movies about the $\mathrm{CCO}$; a debate and a round table on 'the $\mathrm{CCO}$, the art of building commonality ${ }^{15}$; and a buffet dinner.

The 50th anniversary celebrations highlighted the importance of action in the identity of the $\mathrm{CCO}$ within the framework of its history, as Olivier Chatelan shows. The CCO is not a 'cultural institution' that gains legitimacy from recognition by its trustees or its public; nor is it a 'project hotel', simply providing services to its partner organizations. 'The way in which it creates things has more to do with the connections that it puts into operation, the people that it mobilizes, and the places that it connects' (Autant-Dorier and Aubry 2014, 56), as the experience of the 50th anniversary celebrations shows. Area residents who came as neighbours, newly minted activists as well as old fighters of the 1960s generation, artists who were active in Asian, African and South American 'cultural' organizations, as well as artists specifically invited for the occasion, academics, students, intellectuals and elected officials all met there. They engaged in the various debates, some of them heated, and they testified to the relationships that they had with the CCO. And yet there was something a little disappointing in all these contributions. We did not learn anything much that was new about the experience that all of these people had of the CCO. Some things were confirmed, including the distance kept by the archbishopric, in the person of the archbishop of Lyon; the activist involvement of the socialist elected officials at the beginning of their careers; the function as an incubator for political consciousness; and the fact that connections with the neighbourhood had become more tenuous. The 50th anniversary celebrations confirmed the prominent position of 'inter', which we already knew about; the depth of activist involvement, along with its corollary-namely, clashes with the extreme right; and the important role the CCO had taken within the landscape of refugee culture and protection in Lyon.

Nevertheless, in retrospect it could be said that the 50th anniversary celebrations were a kind of epiphany, a reminder to the members of the CCO of everything that had been important to them since the centre was founded, everything that each of them cared about, and that the celebrations made it possible to set down in black and white; to present all this to the public in a substantial way and, finally, to pass it on, in particular such themes as hospitality, interculturalism, respect for otherness and commitment-nothing really new, in the end. And yet the 50th anniversary can be seen as an affirmation of the fact that what really matters, above all, is putting into practice and renewing 


\section{Author's Proof}

M. RAUTENBERG

what one is in daily life, in a collective act that, on this occasion, is produced by the organization of a commemorative event. It is indeed a matter of heritage because it is something people care about, it is the very heart of this 'CCO spirit' that is often referred to but hard to explain, something that has been asserted for decades, it seems, which shows that it matters to people that it be passed on. This heritage could be considered to be 'weak' because, like Granovetter's weak ties (1983), it seems to be all the stronger for not being very institutionalized and for having been built up without a lot of fuss, which gives it that much more leverage in its ties to other groups and organizations without trespassing on their uniqueness. It is effective because it is open, and because it is not constrained by canonical narratives, iconic images, or sites that must be protected.

\section{Conclusion}

In conclusion, let me return to the three situations that I proposed at the beginning. The gentrification of Palma de Mallorca-though one could of course have found something very similar in many other places like it-brings the urban politics of the rehabilitation of old neighbourhoods and the desire to keep property values up face to face with the residents' attachment to a local neighbourliness that they consider to be their heritage. The heritagization in this case has to do with spaces, buildings and lifestyles all at the same time. It involves public policies as well as residents, but it can also be an instrument for mobilizing opposition to governmental heritage policies. In Villeneuve d'Ascq, the heritagization of the founding utopias seems tenuous; it has not been asserted very much or at all, it is not very visible within the urban space for anyone who does not know the city's history, and yet, from time to time, these utopias reappear in the public discourse, in the commitment of certain residents to their neighbourhoods or in citizen initiatives. There is no real network of residents and elected officials upholding this heritage, and yet, in our research, individuals who were strangers to each other or only slightly acquainted used almost exactly the same discourse of nostalgia about the city's past and seemed ready to defend the values and ideas which had been adopted 30 years earlier. These utopias still retain some of their symbolic and social effectiveness, much like the more or less idealized imaginary of the neighbourliness of Palma de Mallorca's working-class neighbourhoods. At the CCO, the spatial and material inscription of the generous ideas of its early years is not obvious, and yet the CCO, too, seems to have managed the feat of having held on to those ideas since the heyday of humanist activism in the 1970s. What we can learn from the CCO example, seen through the celebration of its 50th anniversary, is that what is truly the heritage in that institution, what the various stakeholders really care about, whether they are activisits, staff members, partners or simply regular visitors, is the 'community' of practices and action constituted by the CCO. This is a community with constantly changing boundaries, which involves multiple activities ranging from accommodating refugees 


\section{Author's Proof}

to cultural activities, from defending 'communitarian' organizations against very sceptical state powers to giving legal and technical aid to foreign artists and facilitating their entry into Lyon's artistic world.

In the end, what these three situations have in common is that the heritage that they create is built through practice; it is a symbolic resource that is activated collectively as a way for groups to defend themselves against things that seem as though they might attack their lifestyles or their ideals. Even if they happen to share some things - such as a taste for neighbourliness, the memory of old utopias that moved them to action in the past, or values of solidarity and hospitality-that is not all that connects all the people involved here. After all, there are many people who could feel affected but who nevertheless keep their distance. What really creates heritage is that these ideals and values are shared, put into movement through action, and that through them, people feel empowered to act publicly. This is not about 'capitalism's cultural shift', which creates economic value through gentrification, nor about the 'heritage communities' that UNESCO protects in order to promote intangible heritage (i.e. the heritage of residents rather than of institutions). This is also not about the territorial marketing that is so beloved by public bodies nor, of course, museological or monumental collecting. What makes these 'weak' forms of heritage so symbolically and socially effective comes down to their ability to mobilize people and groups, and that must be constantly renewed.

1. http://www.coe.int/fr/web/conventions/full-list/-/conventions/rms/ 09000083746.

2. This research was carried out in two phases. The first, from 2002 to 2003 , was a collective project examining the evolution of the notion of public space in new cities. The second, from 2002 to 2006, looked at the production of intermediate spaces in the vicinity of Villeneuve d'Ascq. This was based on multiple sources: interviews in the Lille region and in Paris with developers, landscapers and architects who had been involved in the construction of the city; regular observations in various contexts, including participation in guided tours of the city, cultural activities, and visiting stores and personal connections (of which we had many because Villeneuve d'Ascq is a university town); a systematic review of the municipal as well as the institutional press from 1977 to 1985 , and again from 2003 to 2005; queries to the National Institute of Statistics and Economic Studies and to city services about the city's sociodemographic data from 1977 to 2006; and in-depth and repeated interviews with 22 residents beyond our personal connections.

3. This neighborhood was not part of the original plans and it was the subject of a memorable battle between the local government and the residents, who were against the project, which was supported by the state and by Etablissement Public d'Aménagement de Lille Est.

4. La Tribune, February 2000, no. 151.

5. I rely here on a collective research project led by the anthropologist Claire Autant-Dorier from 2012 to 2014 . The team included a social psychologist, an

618 


\section{Author's Proof}

M. RAUTENBERG

anthropologist, a videographer, a doctoral student in anthropology, the historian Olivier Chatelan and me. I have been involved with the centre since 2007, helping to facilitate its work. I have also participated in several studies and reflections on its workings and its institutional memory, particularly the 50th anniversary project, which is described later. During the latter, I was involved as a member of the research steering committee and a co-director of the thesis.

6. Father Jean Latreille came from a family of socially active Catholics who were well known in Lyon, which allowed him to involve a number of Lyon's industrial employers in the CCO's early years.

7. 'Christmas parties' are popular traditional events that gather the employees or stakeholders together in the last days before the Christmas holidays in many companies, associations and public offices. They are called 'Christmas trees' (arbres de Noël).

8. From a speech by President Jean-Michel Privolt (1983-1987) (quoted in Chatelan 2012, p. 31).

9. For example, in 1985 the CCO supported the creation of the Villeurbanne Organization for Housing Rights (Association villeurbannaise pour le droit au logement), whose first goal was to facilitate access to decent housing for foreigners. The organization had its headquarters at the CCO, which provided rent-free rooms and equipment. The permanent staff and the board members of the CCO were involved in the life of the organization as well (Chatelan 2012).

10. Arising in the early 1980s in response to the social issues around subsidized housing areas, these policies became institutionalized during the following decade.

11. My emphasis.

12. One of the main cultural events organized every year by the CCO.

13. A book sprint is an intensive collaborative writing practice which takes place over several days (in this case five days). Twelve people participated, writing online on the CCO's core topics: connection to communities, attachment to a universe that feeds on diversity, involvement and social transformation.

14. Based on interviews that had been carried out beforehand, the participants were asked to role-play encounters.

15. Quotations here are from the programme for the event.

Adell, Nicolas, Regina F. Bendix, Chiara Bortolotto, and Markus Tauschek, eds. 2015. Between Imagined Communities and Communities of Practice: Participation, Territory and the Making of Heritage. Göttingen: Universitätsverlag Göttingen.

Auclair, Elisabeth, and Graham Fairclough, eds. 2015. Theory and Practice in Heritage and Sustainability. Between Past and Future. London: Routledge.

Autant-Dorier, Claire, and Anne Aubry. 2014. Pratiques (inter)culturelles et institution d'un patrimoine. 50 ans d'activités au CCO Jean-Pierre Lachaize (Villeurbanne). Villeurbanne: Centre Max Weber, CCO Jean-Pierre Lachaize, Le Rize, Ministère de la culture et de la communication.

Bacqué, Marie-Hélène, and Carole Biewener. 2013. L'Empowerment, une pratique émancipatrice. Paris: La Découverte.

Bandarin, Francesco, and Ron van Oers. 2014. Reconnecting the City: The Historic Urban Landscape Approach and the Future of Urban Heritage. London: Wiley Blackwell. 


\section{Author's Proof}

THE STRENGTH OF WEAK HERITAGES: URBANITY, UTOPIAS...

Chatelan, Olivier. 2012. Le centre culturel acuménique (CCO): un lieu atypique. Villeurbanne: Centre Culturel Ecuménique Jean-Pierre Lachaize.

Choay, Françoise. 1965. L Urbanisme, utopies et réalites: Une anthologie. Paris: Seuil. 690

Dicks, Bella. 2000. Heritage, Place and Community. Cardiff: University of Cardiff 691 Press.

Granovetter, Mark. 1983. The Strength of Weak Ties: A Network Theory Revisited. 693 Sociological Theory 1: 201-233.

Harvey, David. 1989. The Urban Experience. Baltimore, MD: The John Hopkins 695 University Press.

Hocquet, Marie. 2013. La patrimonialisation du centre historique de Berlin, un oubli 697 programmé? Le réaménagement de la place du château. Espaces et Sociétés: 67-84. 698

Isnart, Cyril. 2015. Self-Heritage-Making and Religious Minority in Greece: An 699 Ethnography of Heritage Activities Outside of the Cultural Institutions. In Between 700 Imagined Communities and Communities of Practice: Participation, Territory and 701 the Making of Heritage, ed. Nicolas Adell, Regina F. Bendix, Chiara Bortolotto, and 702 Markus Tauschek, 171-183. Göttingen: Universitätsverlag Göttingen. 703

Labadi, Sophia. 2013. Unesco, Cultural Heritage, and Outstanding Universal Value. 704 Plymouth: Altamira Press.

Le Galès, Patrick. 2003. Le retour des villes européennes. Paris: Presses de Sciences Po. 706

Morell, Marc. 2015. La Flor y Muerte de un Barrio. An Ethnography on Comprehensive 707 Gentrification and Class Struggle in Urban Majorca. Doctoral Thesis, Universitat de 708 Barcelona.

Morell, Marc, and Jaume Franquesa. 2011. Playing Snakes and Ladder in Ciutat de 710 Mallorca: An Ethnographic Approach to the Neighbourhhod Scale. In Contested 711 Mediterranean Spaces. Ethnographic Essays in Honour of Charles Tilly, ed. Maria 712 Kousis, Tom Selwyn, and David Clark, 195-220. Oxford: Berghahn Books. 713

Rautenberg, Michel. 2015a. L'urbanité comme patrimoine de la ville. In Le posi- 714 tionnement de l'anthropologie urbaine, ed. Italo Pardo, Giuliana B. Prato, and 715 Wolfgang Kaltenbacher. Diogène, Special Issue, 3-4 (251-252): 90-102. 716

- 2015b. L'identité d'une ville nouvelle aux prises avec ses utopies fondatrices. In 717 S'approprier la ville. Le devenir-ensemble, du patrimoine urbain aux paysages cul- 718 turels, ed. Lucie K. Morisset, 143-154. Montréal: Presses de l'université du Québec. 719

Salzbrunn, Monika. 2015. The Place-Making of Communities in Urban Spaces: The 720 Invention of the Village Saint-Louis Sainte-Marthe. In Between Imagined 721 Communities and Communities of Practice: Participation, Territory and the Making 722 of Heritage, ed. Nicolas Adell, Regina F. Bendix, Chiara Bortolotto, and Markus 723 Tauschek, 185-199. Göttingen: Universitätsverlag Göttingen.

Secchi, Bernardo. 2004. La ville contemporaine européenne et son projet. In 725 L'imaginaire aménageur, ed. Yves Chalas, 121-155. Paris: L'Harmattan. 726

Smith, Laurajane, and Natsuko Akagawa. 2009. Intangible Heritage. London: 727 Routledge.

Tornatore, Jean-Louis. 2006. Les formes d'engagement dans l'activité patrimoniale. De quelques manières de s'accommoder au passé. Questions de communication, série actes 3: Formes de l'engagement et espace public: $515-538$.

AU9 Vadelorge, Loïc. 2003. Des villes sans histoire. Ethnologie française XXXVII: 21-30.

Wenger, Etienne 1998. Communities of Practice: Learning, Meaning, and Identity 733 Cambridge: Cambridge University Press.

8

9

\section{.}

4

96

\section{8}

0

2

3

5

6

8

9

。

1

3




\section{Author's Proof}

M. RAUTENBERG

735 Michel Rautenberg is Professor of Sociology at the University of Saint-Etienne, 736 France. He has done fieldwork in France, Bulgaria and Wales, specializing in urban 737 anthropology and heritage studies. He is a founding member of the International 738 Urban Symposium and serves on the Scientific Board of Urbanities-Journal of Urban 739 Ethnography. He has published several books and articles on cultural heritage, collective 740 memory, public policies and social imagination. He has recently initiated research on 741 'Pratiques (inter)culturelles et institution d'un patrimoine 50 ans d'activités au CCO742 Jean-Pierre Lachaize (Villeurbanne)'. 


\section{Author's Proof}

\section{Author Queries}

Chapter No.: 17

0003176141

\begin{tabular}{|c|c|c|}
\hline Queries & Details Required & Author's Response \\
\hline AU1 & $\begin{array}{l}\text { Please check and confirm the affiliation details and amend if } \\
\text { necessary. }\end{array}$ & \\
\hline AU2 & $\begin{array}{l}\text { In "The heritage field has grown considerably in recent } \\
\text { decades,", please avoid non-specific time-relative phrases (e.g. } \\
\text { in recent decades) and change to a specific date range, the } \\
\text { timing of which will remain clear even as this book dates. } \\
\text { Please check for such phrases throughout. }\end{array}$ & \\
\hline AU3 & $\begin{array}{l}\text { In "The atmosphere can become tense when the residents } \\
\text { believe that their points of view are not being heard. Later, } \\
\text { other systems were set up to" the tense changes from present } \\
\text { to past. Please review tense changes here and throughout and } \\
\text { make tense consistent where appropriate. }\end{array}$ & \\
\hline AU4 & $\begin{array}{l}\text { Please clarify meaning of "From Urban Utopias to the } \\
\text { 'Imaginary in Act' of Local Residents". }\end{array}$ & r \\
\hline AU5 & $\begin{array}{l}\text { Where possible, please place note cues at the end of the } \\
\text { relevant sentence. E.g. cue for Note } 6 \text {. }\end{array}$ & \\
\hline AU6 & $\begin{array}{l}\text { Please insert opening quote mark to match closing quote mark } \\
\text { in "a growth of } 800 \text { percent in terms of hours of presence in the } \\
\text { building from } 1987 \text { to } 1989 \text { ".". }\end{array}$ & \\
\hline AU7 & $\begin{array}{l}\text { In "The problem for the staff members and activists was that it } \\
\text { was "less about leaving a mark than about becoming involved } \\
\text { in the relationship and making things happen, "working } \\
\text { together"", please add closing quote mark to match opening } \\
\text { quote mark before "less". }\end{array}$ & \\
\hline AU8 & $\begin{array}{l}\text { Please provide the volume number for the reference "Tornatore } \\
\text { (2006)". }\end{array}$ & \\
\hline AU9 & $\begin{array}{l}\text { Please check and confirm the inserted volume number for the } \\
\text { reference "Vadelorge (2003)". }\end{array}$ & \\
\hline
\end{tabular}

